\title{
ArcheoSciences
}

Revue d'archéométrie

33 (suppl.) | 2009

Mémoire du sol, espace des hommes

\section{From training ground to battlefield: Recording the archaeology of the Great War}

Peter Masters

\section{(2) OpenEdition \\ 1 Journals}

Electronic version

URL: https://journals.openedition.org/archeosciences/1379

DOI: 10.4000/archeosciences. 1379

ISBN: 978-2-7535-1599-4

ISSN: 2104-3728

Publisher

Presses universitaires de Rennes

Printed version

Date of publication: 30 October 2009

Number of pages: 109-110

ISBN: 978-2-7535-0943-6

ISSN: $1960-1360$

Electronic reference

Peter Masters, "From training ground to battlefield: Recording the archaeology of the Great War", ArcheoSciences [Online], 33 (suppl.) | 2009, Online since 30 October 2011, connection on 01 February 2022. URL: http://journals.openedition.org/archeosciences/1379 ; DOI: https://doi.org/10.4000/ archeosciences. 1379 


\title{
From training ground to battlefield: Recording the archaeology of the Great War
}

\author{
Peter Masters*
}

Key words: Gradiometer, Magnetic anomalies, First world war, Aerial photography, Training.

Conflict Archaeology is a rapidly developing sub-discipline within the traditional field of archaeology and has only recently started to receive attention from professional archaeologists. Non-destructive methodologies such as the study of aerial photographs and the use of geophysical prospection techniques can provide a means of effective cultural resource management.

Geophysics is beginning to play an important role in recording past landscapes of conflict. Over the past three years, Cranfield University has been carrying out research in recording such landscapes from the training grounds to the actual fields of conflict.

Large areas of Salisbury Plain, UK, were given over to training for trench warfare on the Western Front during the First World War. Some of these still survive as earthwork remains but the majority were back-filled by troops waiting for demob at the end of the war. Aerial photographic evidence shows how extensive these trench systems could be but little survives today to mark their existence. By using archaeological geophysics, Cranfield University has attempted to reveal the extent of these trenches with some success.

From the work carried out on Salisbury Plain, the application of geophysical survey techniques has been carried out at Ploegsteert, Belgium in the last three years to detect and record the remains of the front line trenches of 1917 of both the British and German lines. This research has been undertaken as part of The Plugstreet Project, which was initiated

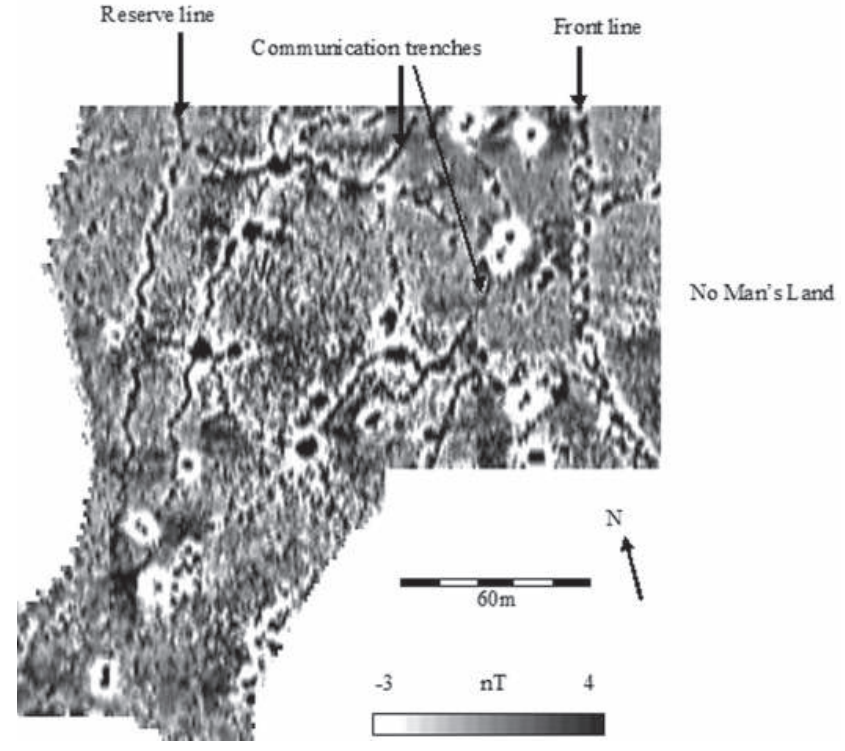

Figure 1: Practice trenches, Perham Down, Salisbury Plain, UK, surveyed using a Bartington Grad 601-2 dual gradiometer.

by No-Man's Land - The European Group for Great War Archaeology (NML) to follow the Australian $3^{\text {rd }}$ Division infantry from training on Salisbury Plain to action in theatre along the Western Front.

* Research Fellow (Geophysics), Centre for Archaeological and Forensic Analysis, Department of Applied Science, Security and Resilience, Cranfield University, Shrivenham, Swindon, Wiltshire, UK, SN68LA. (p.masters@cranfield.ac.uk) 
Millions of aerial photographs of the frontline were taken during the Great War of 1914-18. Aerial photographic evidence shows how extensive these trench systems were but little survives to mark their existence today. Most of the fields where the action took place have now returned to their pre-war state as agricultural land. By using archaeological geophysical techniques in combination with the extensive aerial photographic coverage of the frontline, it has been possible to map accurately the location of these trench systems as well as record the remains of No Man's Land, previously unrecorded by such scientific investigation. It has been previously thought that such techniques would not work.

Undertaking surveys in No Man's Land between the front lines of the First World War has been problematic with the unexploded ordnance to ferrous remains scattered on or near the surface across the landscape especially shrapnel, shell cases etc. Today, many of these remains are no longer visible as upstanding earthwork remains as the fields in which these trenches were dug were returned to their original use after 1918 and to this day are continually under arable cultivation.

Over the past three years an extensive landscape has been recorded with some accuracy by comparing and correlating the evidence from aerial photographic coverage to the trench maps that were produced during the war. A number of these anomalies have also been tested by archaeological investigation through trial excavation.

An area of some 16ha has been surveyed to date using a Bartington Grad-601 dual gradiometer at Ploegsteert covering an area from the British Allied line across No Man's Land and beyond the German front line. The survey area was divided into $30 \mathrm{~m}$ squares with readings taken at $0.25 \mathrm{~m}$ intervals along traverses spaced at $1 \mathrm{~m}$ apart in the $0.1 \mathrm{nT}$ resolution.

Further work is planned to include the detection of structures such as concrete bunkers and mineshafts as well as gun emplacements. The use of earth resistance and ground penetrating radar has been problematic due to the geology, but by adapting and reconfiguring the techniques it is possible to locate such features beneath the plough soil.

This poster will demonstrate how effective the use of gradiometry can be to detecting remains of these practice trenches on Salisbury Plain to the battlefields of the Western Front, in particular the trench remains at Ploegsteert (Plugstreet), Belgium. 